ENTREPRENEURSHIP AND SUSTAINABILITY ISSUES

ISSN 2345-0282 (online) http://jssidoi.org/jesi/

2020 Volume 7 Number 3 (March)

http://doi.org/10.9770/jesi.2020.7.3(31)

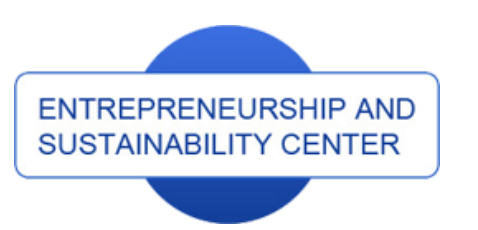

Publisher

http://jssidoi.org/esc/home

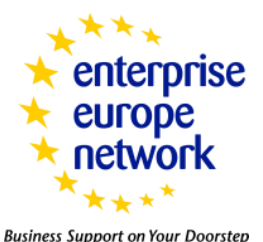

Business Support on Your Doorstep

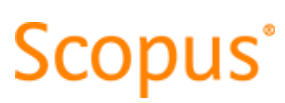

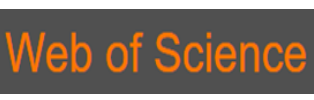

Clarivate
Analytics

\title{
SYNERGY - AN ENHANCEMENT OF LEARNING ORGANISATIONS UNDERGOING A CHANGE ${ }^{*}$
}

\author{
Monika Jasińska \\ Siedlce University of Natural Sciences and Humanities, Faculty of Social Sciences, \\ Konarskiego Street 2; 08-110 Siedlce, Poland \\ E-mail: monika.jasinska@uph.edu.pl \\ Received 15 July 2019; accepted 10 December 2019; published 30 March 2020
}

\begin{abstract}
Innovative development of an organisation requires good management practice based on introducing creative solutions, this however can only be possible by making each member of the organisation aware of the value of team learning. This ability to build a creative environment, by means of an apt quality of teamwork shaped by good cooperation and its benefits, especially during a time of change, produces opportunities for better adaptation and distinction of an organisation. By developing the team's activity, one can achieve an enhancement effect - the synergy. The aim of the article is to verify the mediation hypothesis on the mediative role of synergy in the team's relations between the team work and the improvement of learning organisation. Thus to present relevant arguments, mixed studies, based on group interviews and a diagnostic survey, were performed. The study applied methods of statistical analysis determining the correlation coefficient factor analysis (CFA) and regression analysis. Consequently, it was noticed that synergy emerging on the basis of high quality teamwork strengthens the impact of team work on improving the learning organisation by introducing innovative changes. It was also found that the management method promoting proactivity supports the development of entrepreneurial activities in a team, but it does not have a direct impact on the synergy in a team. The study showed that the quality factors of teamwork are supported by social potential, which is important for shaping the level of team working in a learning organisation.
\end{abstract}

Keywords: activity; team work; synergy; change; social potential; team learning

Reference to this paper should be made as follows: Jasińska, M. 2020. Synergy - an enhancement of learning organisations undergoing a change. Entrepreneurship and Sustainability Issues, 7(3), 1902-1920. https://doi.org/10.9770/jesi.2020.7.3(31)

JEL Classifications: L20, L26, O15, M54

Additional disciplines: sociology, psychology.

\footnotetext{
*The paper has been prepared on the basis of a fundamental research project - Synergy and Social Capital of Modern Organisations. The project was financed by the National Science Centre with funds allocated on the basis of decision-DCE 2011/01 / BHS4 / 04810.
} 


\section{ENTREPRENEURSHIP AND SUSTAINABILITY ISSUES}

ISSN 2345-0282 (online) http://jssidoi.org/jesi/

2020 Volume 7 Number 3 (March)

http://doi.org/10.9770/jesi.2020.7.3(31)

\section{Introduction}

With the social and economic growth there is a need to make space for creative and entrepreneurial activity. The space is available in the knowledge oriented organisations, which cooperate on different levels both externally and internally, all to create the new quality of knowledge. In the even an organisation reaches the ability to use the potential of knowledge and experience gained on the basis of joint action it increases its power to adapt to the changing environment. Under these circumstances, the change should be considered a key process and source of progress. In order to generate positive social, economic and technological effects when implementing a change one should take into account the assumptions of the concept of sustainable enterprise, learning organisations and leadership.

New, changeable and dynamic reality puts many development challenges and opportunities for organisations and people functioning in them. On the other hand, it also carries many threats and limitations, which could be alleviated provided everybody starts working as a team. Therefore, the development of the concept of real changes in an organisation requires a system approach, thinking in terms of achieving a joint effect and great diligence at the stage of determining the direction of change. Hence, the commitment of each participant in the organisation and their ability to react properly to change (Sange P., 2014) is the required foundation.

Effectiveness can only be achieved if the participants in the change process are aware of where they are going and what they are supposed to achieve. Organisations defining their way of development should develop their own model of action, which will not only determine their effectiveness, but also differentiate them and take the role of a creator of change. In this context, organisations adhering to new directions of action must take into account the essential elements determining the efficiency of functioning. Above all, however, they should take up the challenge of implementing innovative changes. The organisations that create perspectives for dynamic development using new technologies, the ability to mobilise knowledge and social potential, and novelties owe their success to innovation (Tidd J., Bessant J.R., 2018; Benešová, D., Kubičková, V., Michálková, A., Krošláková, M. 2018).

Any organisation undergoing an innovation process, which is an intricate social procedure, faces challenges with respect to building and using team working, i.e. the essentials to enhance learning opportunities for the sake of mutual improvement. While engaging in the changes, the team working creates the foundation for emergence of cognitive openness, creativity in team work, team learning or entrepreneurial action. A well-organized teamwork enables the potential of team working people, increases their activity and efficiency. In a learning organisation, the value of teamwork is created based on knowledge sharing, namely knowledge conversion, which increases the possibility of creating good conditions for synergy. Given all that, it is the synergy that reinforces team work and an expresses high-quality relations. The synergy as an effect of people's activity in team work creates team's strength and increases the ability to generate creative solutions. Thus, it can be concluded that the effect of synergy in team working facilitates and accelerates the process of innovative changes, which is an additional contribution to the development of all an organisation, a team and each unit participating in the process.

\section{Progress fundamentals of learning organisations}

When preparing their strategies, development and competitive advantage oriented organisations include programs and follow-ups for continuous improvement and refinement of efficiency (Park S.H., Zhang Y., Keister L.A., 2019; Jelenic D., 2011; Kaur S., 2015). This approach requires certain commitment level of all stakeholders in the process of mutual learning (Bratianu C., 2015). Business practice itself makes a visible connection between continuous improvement and learning organisation (Rusly F.H., Corner J.L., Sun P., 2012; Loermans J., 2002). The majority of learning organisation concepts show that organisational learning should be considered a complex process that is created and implemented at a given time. In order to conduct the procedure, one must either get the 


\section{ENTREPRENEURSHIP AND SUSTAINABILITY ISSUES}

ISSN 2345-0282 (online) http://jssidoi.org/jesi/

2020 Volume 7 Number 3 (March)

http://doi.org/10.9770/jesi.2020.7.3(31)

know-how from external experts or try to use its own assets (King W.R. (ed.), 2009). The organisational learning triggers better performance of people, teams and the entire company (Garvin D.A., 1993).

Now, when attempting to interpret definitions of a learning organisation, their diversity cannot be unnoticed, they pay attention to different dimensions that are signifiant from approach, measurement, and evaluation perspectives. Generally, it can be assumed that a learning organisation is capable of creating, acquiring and transferring knowledge (King W.R., Chung R.T., Haney M.H., 2008). It can modify behaviours in order to create a new quality of knowledge and good practice (Sange P., 2014). New ideas expressing creativity base on illumination, sharing insights and experiences during team working. They are a compilation from various sources of knowledge, and this makes them necessary to initiate the learning process. Regardless of the source, the goal of the ideas produced is to improve organisational activities and develop custom solutions to emerging problems. Creating only ideas, however, is not enough to build a learning organisation. In this aspect, it is necessary to introduce changes in thinking, behaviours and actions.

In the learning organisations environments people systematically develop their ability to create the consciously defined and achieved results, which motivate progress (Černevičiūtè, J., Strazdas, R. 2018). These organisations provide the space for promoting and implementing new thinking patterns (Senge P., KleinerA., Roberts Ch., Ross R., Roth G., Smith B., Guman E.C., 2007), they trigger collective aspirations, and prompt people to constantly learn how to study together (Sange P., 2014). Learning new knowledge, in learning organisations, is a way of conduct, life, where everyone is a knowledge worker (Nonaka I., 1991). Therefore, team learning is an exceptional value that creates a high quality of social potential in an organisation. That potential is capable of converting knowledge, openness, cognitive flexibility, and knowledge sharing (Huber G.P., 1999). The management foundation of learning organisation must build sufficiently collaborative work environment, that skilfully combines the generation and exploitation strategy which in turn establishes favourable conditions for the emergence of synergy in team work (Corning P., 1996; Corning P., 2018). Thus, the culture supporting social capital and team work is indispensable (Maull R., Brown P., Cliffe R., 2001; Jasińska, 2019(2)). Its strength comes from the fact that it emerges naturally on the basis of high-quality cooperation and mutually reinforcing interactions, i.e. well-arranged relations (Jasińska M., 2015).

The development pillars of learning organisations are knowledge and innovation, which find their grounds in creativity, entrepreneurial actions and team work (Albrecht, 2003; Jasińska, 2019(1)). These are the elements, that in the conditions of change and the complexity of the organisation's environmental relations, can be considered the most important forces stimulating efficient and creative action (Černevičiūtè, J., Strazdas, R. 2018). They also encourage creation of new solutions, generation of new quality of knowledge and production of added value.

Often, companies with classic profiles, expect innovation, so it is no longer just a domain of the so-called advanced technologies (Tidd J., 2012). The growing role of creativity in many economies means that in complex systems (society, organisations) in which the ethos of creative work is more and more dominant, innovation becomes a natural mechanism for the development of the whole, but also of individual parts of the system (Florida R., 2014). The direction of innovative changes, strengthened by the building of high-quality social potential, creates the perspective of well established and sustainable development. This is an additional boost and a safety increase factor. Innovation in an organisation is a process in which ideas become a reality and generate tangible benefits for the organisation (Tidd J., Bessant J.R., Pavitt K., 2015). In this context, innovation needs a specific space for its development, so that it can exist and be a force pushing improvement in an organisation. It is a set of elements comprising a larger system since it changes both the individual elements and the entire system (Tidd J., Bessant J.R., 2018).

Innovation means gaining knowledge, opening to new opportunities by matching and combining different sets of knowledge, which, we cannot forget that, often takes place under conditions of uncertainty. Activities related to 
ENTREPRENEURSHIP AND SUSTAINABILITY ISSUES

ISSN 2345-0282 (online) http://jssidoi.org/jesi/

2020 Volume 7 Number 3 (March)

http://doi.org/10.9770/jesi.2020.7.3(31)

innovative development require giving impulse for change and presenting a vision defining the direction and ways of its implementation. At this stage, it is important to properly reinforce the leaders of change and motivate employees to participate in it. The role and challenge for managers, using combination of ideas, knowledge and skills to obtain a new value, is to shape appropriate conditions for synergic action,. Learning organisations, especially in conditions of innovative changes, require a clear determination of the forces that mobilise their functioning and development. Figure 1 presents the relationship between the factors constituting the basis for the development of a learning organisation, which will be under empirical analysis in the following part of the article.

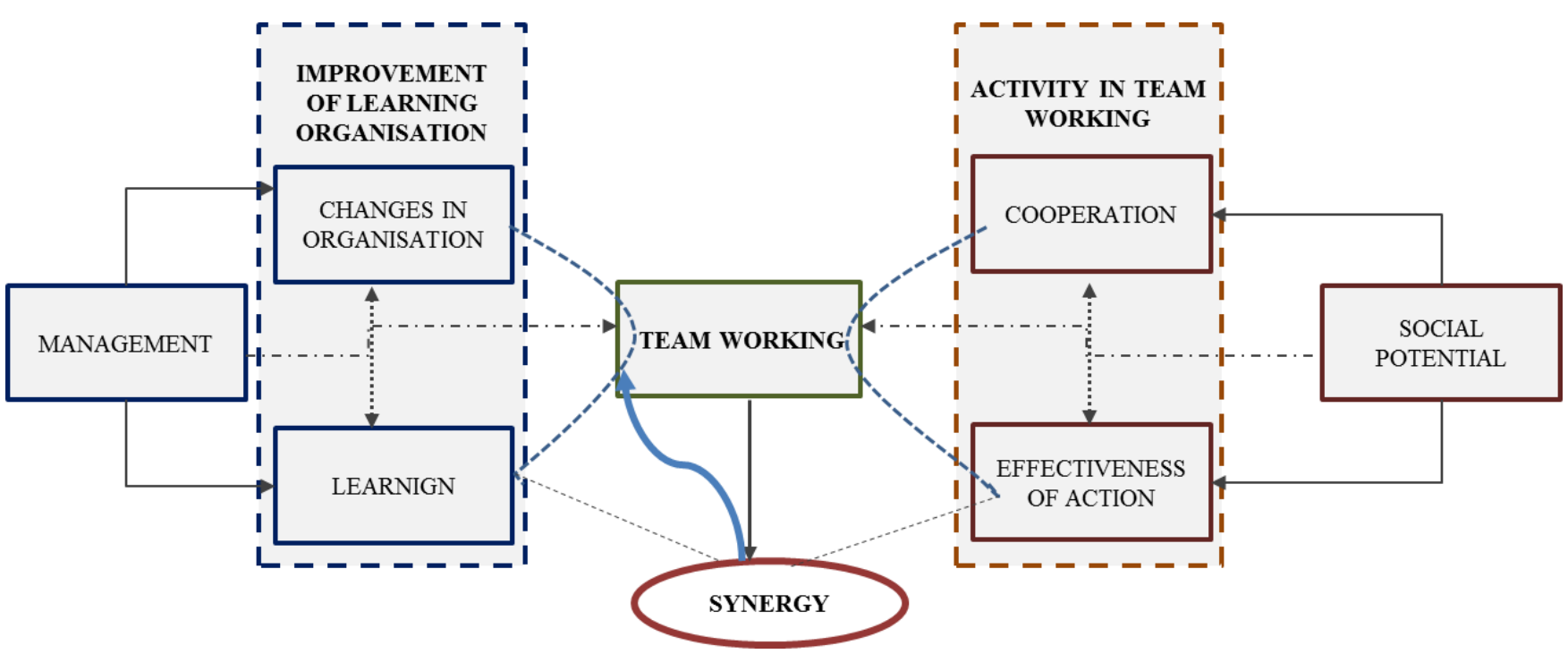

Fig. 1. Enhancing factors of learning organisation undergoing a change

Source: own study

\section{Research Methodology}

The procedure of identifying and analysing the premises for the occurrence of synergy in team work was carried out on the basis of three stages and each contributes significantly to exploring the knowledge about the conditions of the synergy phenomenon. Additionally, they are important for successive empirical actions, thus maintaining an appropriate structure of actions. The research and analytics, determined in the sequence, constitute the ending point, and also the observation of new dimensions of the analysis. Due to the complexity of the process of determining and analysing the prerequisites of synergy in a team, this article is an indication and a summary of the most important results of qualitative research. The main analysis (quantitative study) presents some of the case study ("P-M" company) results of the preliminary research stage. The layout and effects of individual stages of the study are presented in Figure 1.

The "P-M" company has been selected for the study due to the experience in the implementation of joint projects, which naturally was an excellent starting point to get good knowledge on how it operates, its directions of change, and awareness of strengths and weaknesses. In other words, all that helped in the consolidation of knowledge about building teamwork in a company. In addition, the general profile of operations has awaken the cognitive 


\section{ENTREPRENEURSHIP AND SUSTAINABILITY ISSUES}

ISSN 2345-0282 (online) http://jssidoi.org/jesi/

2020 Volume 7 Number 3 (March)

http://doi.org/10.9770/jesi.2020.7.3(31)

curiosity while selecting the study subject, since the "P-M" company is distinguished by its complexity in terms of: the scope of operations, implemented tasks, created processes, relations with the surrounding, a large diversity of teams, and company's size (big). Based on the management method and the applied development philosophy, it can be assumed that the "P-M" company operates by principles of the learning organisations. This example of the complexity of the company's operation was considered important and potentially tempting to explore the synergy conditions in a team.

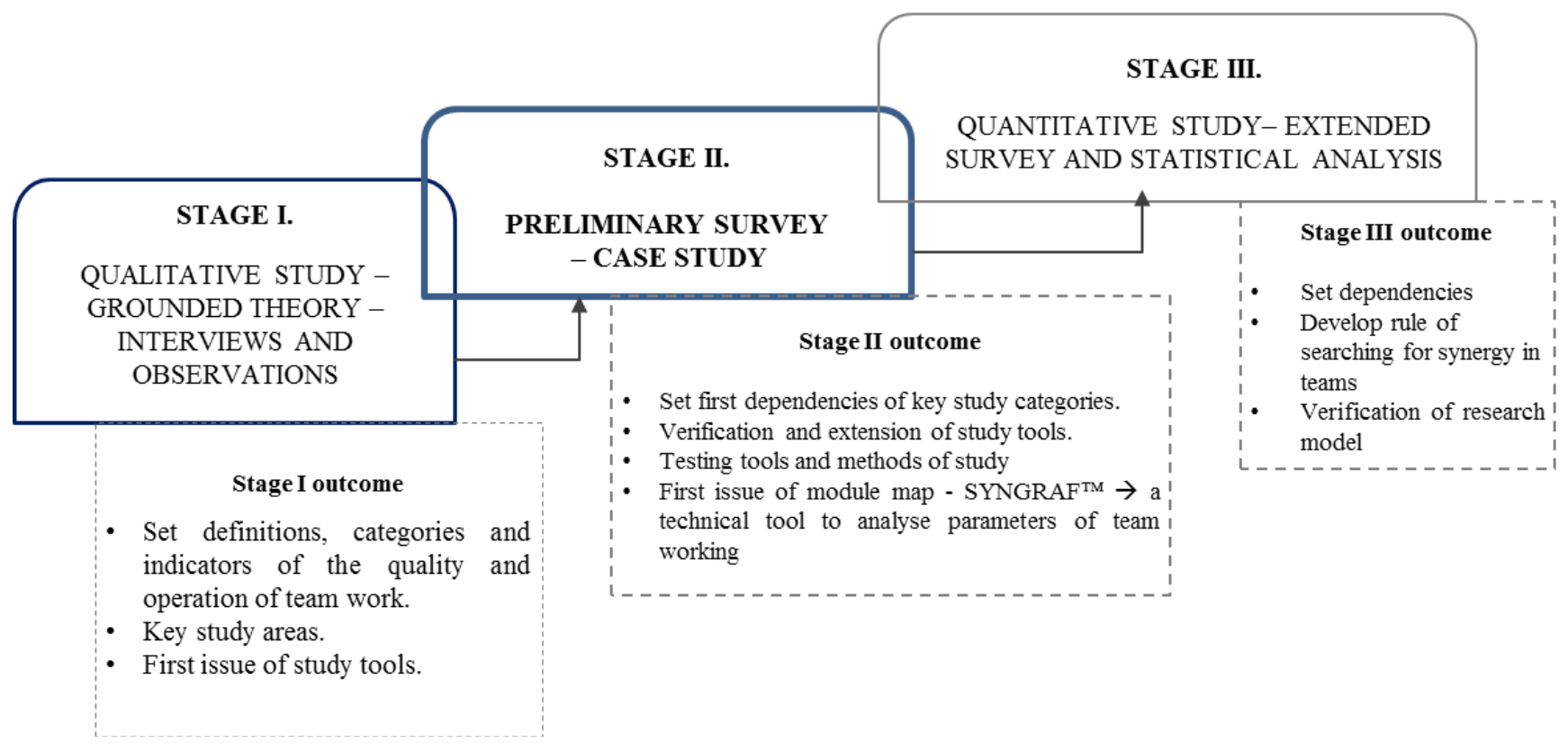

Fig. 2. Research stages in the analysis procedure of synergy conditions in a team

Source: own study

The first action in the process was to recognise the importance of teamwork in the development of an organisation. In this aspect, the potentially important empirical areas have been identified in order to enable implementation of further stages of the procedure and data analysis (Jasińska, 2019(1)). The results of this part of the proceedings encouraged and gave directions for the qualitative research, which has been performed by means of the grounded theory (Konecki K.T., 2011). Implementation of this strategy is based on in-depth individual and focus group interviews as well as participant observation. The sampling took place in the natural environment of teams' operations, observing the principle of saturation of the theoretical material (Charmaz K., 2014). The collected data was transcribed, verified and developed in accordance with the principles of qualitative analysis, based on the grounded theory procedure (Konecki K.T., 2009).

The exploration and description made it possible to build categories that were used in the development of code sheets and subsequent study scenarios. The value of the defined during the field study concepts, phenomena, the most characteristic behaviours, the determination of the first significant dependencies, derives from the description of the directly observed and surveyed group of employees cooperating with each other in a team. The procedure under the grounded theory was one of the most important steps in the research process. It allowed, in addition to recognising the basis of the quality of teamwork, to determine the main variables, indicators and characteristics validating the conditions of synergy in a team Jasińska, 2019(1)). And at the stage of preliminary 
surveys, these conditions were examined and verified, and then, in the main study (stage III of the procedure), analysed.

A total of 88 interviews (73 individual and 15 group) conducted with members of 22 teams over 140 hours (average interview time 97 minutes), with an active participation of 214 people was the real chance for natural observation of team work. The selection of teams was intentional and based on a list prepared by the HR department. That list was used to select study teams meeting three basic criteria: size, type and level of efficiency at work. Table 1 presents the features of teams participating in the study, all in accordance with the strategy of grounded theory.

Table 1. Characteristics of teams in individual and focus group interviews

\begin{tabular}{|c|c|c|c|c|c|c|c|c|}
\hline \multirow{2}{*}{ Size, type and efficiency level } & \multirow{2}{*}{$\begin{array}{c}\text { Number of } \\
\text { teams (number } \\
\text { of people) }\end{array}$} & \multicolumn{2}{|c|}{ Gender } & \multicolumn{5}{|c|}{ Age } \\
\hline & & $\mathbf{F}$ & $\mathbf{M}$ & $>\mathbf{3 0}$ & 30-39 & $40-49$ & $50-59$ & $\leq \mathbf{6 0}$ \\
\hline \multicolumn{9}{|c|}{ In-depth individual interviews $-\mathbf{N}=73$} \\
\hline small $* * / *(p j)$ & $2(12)$ & 9 & 3 & - & 2 & 8 & 1 & 1 \\
\hline average $* * / * * / *(\mathrm{pj})$ & $3(23)$ & 11 & 12 & 1 & 9 & 10 & 3 & - \\
\hline big $* * / *(\mathrm{pj})$ & $2(24)$ & 15 & 9 & - & 10 & 11 & 3 & - \\
\hline Managerial staff & - (14) & 6 & 8 & - & 3 & 7 & 4 & 1 \\
\hline \multicolumn{9}{|c|}{ Group interviews - Focus group - N = 141} \\
\hline $\begin{array}{l}\text { small } * * / * * / * * / * * / * \\
(\mathrm{~m}, \mathrm{pj}, \mathrm{ts}, \mathrm{o}, \mathrm{a})\end{array}$ & $5(27)$ & 13 & 14 & - & 10 & 13 & 3 & 1 \\
\hline $\begin{array}{l}\text { average } * * / * * / * / * / * \\
(\mathrm{~m}, \mathrm{pj}, \mathrm{ts}, \mathrm{o}, \mathrm{a})\end{array}$ & $5(38)$ & 21 & 17 & 2 & 18 & 13 & 4 & 1 \\
\hline $\begin{array}{l}\text { big } * * / * / * / * / * \\
(\mathrm{~m}, \mathrm{pj}, \mathrm{ts}, \mathrm{o}, \mathrm{a})\end{array}$ & $5(76)$ & 43 & 33 & 5 & 31 & 24 & 13 & 3 \\
\hline \multicolumn{2}{|l|}{$S(N=214)$} & 118 & 96 & 8 & 83 & 86 & 31 & 6 \\
\hline
\end{tabular}

Source: own study.

The first step included in-depth individual interviews, which were conducted with members of 7 project teams (73 people) and both senior and middle managerial personnel (14 people). Alongside the collection of empirical material, in form of notes, it was transcribed, coded and analysed. The focus group interviews, effected on 15 (141 people) proportionally selected teams, were an extension and supplement of the entire process. Following the 3 set criteria, the following teams participated in the second part of the qualitative study: 5 teams - big, medium and small, and 3 - design, management, advisory, operational and trouble shooting teams.

The data was both audio (voice recorder) and notes and it was used to elaborate the coding principles and the code sheet. This procedure established the main research categories and frequency of indicating them. Additionally it interpreted the approach and identified manifestations of synergy phenomenon. That was the basis for a 


\section{ENTREPRENEURSHIP AND SUSTAINABILITY ISSUES}

ISSN 2345-0282 (online) http://jssidoi.org/jesi/

2020 Volume 7 Number 3 (March)

http://doi.org/10.9770/jesi.2020.7.3(31)

qualitative statistical analysis using the method of assessing basic dependencies - the rho-Spearman correlation coefficient. Employing the knowledge obtained in the qualitative study, and the results of analysis, the first version of the research tools set was developed. The questionnaire consisted of 120 statements identifying the level of teamwork and 20 describing the way of managing and the company's standing. Furthermore, to measure individual features, a 5-point Likert scale was used, assuming that 1 is the lowest and 5 the highest value.

The results of qualitative research analysis triggered the second stage of the research procedure - preliminary surveys. The aim of the work was to verify the reliability of research tools and determine the key factors defining the quality of team work and development of an organisation. Using the method of a diagnostic survey, 200 people - members of 22 teams who were involved in individual and group interviews were studied. Taking into account the characteristics of the research sample, respondents differed among themselves in terms of gender, age, level of education, seniority, time of working in a team and experience in team work.

The main direction of the analysis was the willingness to explore interesting relations and phenomena of data segmented for analysis. One of the dependencies of special empirical interest is: Synergy in a team arises on the basis of high quality teamwork and activity in a team work. In this context, quantitative methods of analysis, based on the assessment of dependences according to Pearson's correlation coefficient, determining factor loadings based on confirmatory factor analysis (CFA) and preparation of basic statistics description - arithmetic mean, SD and determination of $\mathrm{V}$-variation coefficient, have been used. The next stage of the quantitative approach was multiple regression analysis. The goal was to determine why the activity in the team work is the improving drive of learning organisation. Thus the question: is synergy (in the satisfaction

approach as a qualitative measure of synergy in a team) a mediating variable supporting the influence of high activity in team work on the direction of improvement in a learning organisation? Regarding the established knowledge, the assumption was made: Synergy (measured by a qualitative measure - satisfaction*) an enhanced outcome of high activity in a team work reinforces the improvement of learners' organisations in terms of innovative changes. The regression analysis was used to verify the mediation hypothesis on the mediative role of synergy in the team's relations between the team work and the improvement of learning organisation. A mediating model was developed according to the scheme shown in Figure 3.

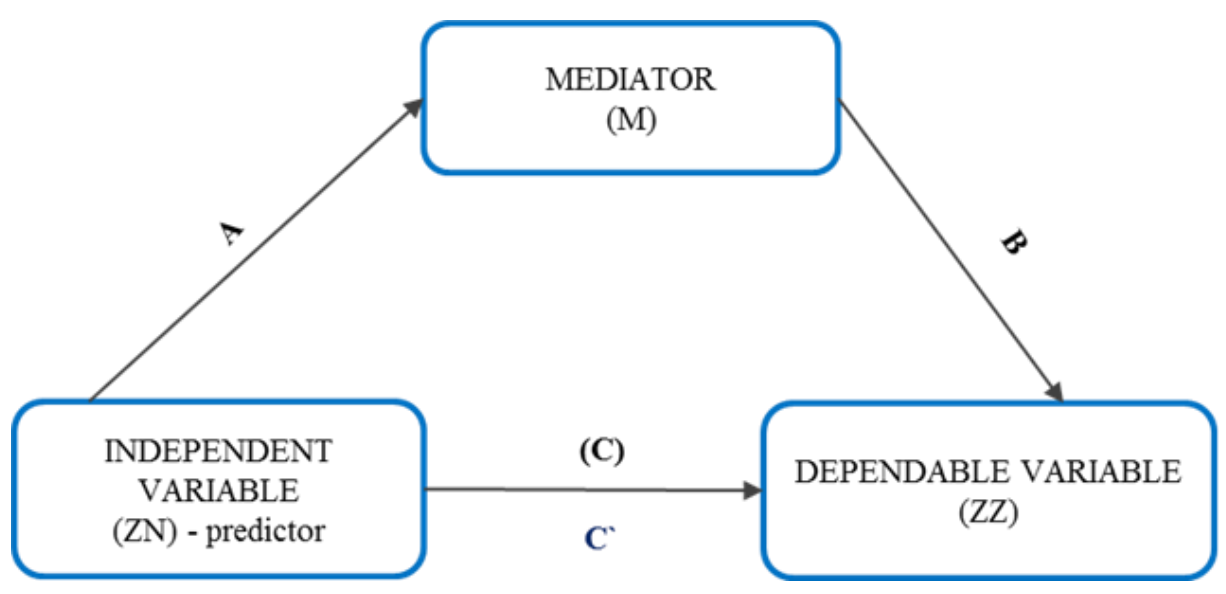

Fig. 3. Diagram of relations in the mediation model

Source: own study.

The Statistica 10 program was used to perform calculations in the scope of quantitative data analysis. 


\section{ENTREPRENEURSHIP AND SUSTAINABILITY ISSUES}

ISSN 2345-0282 (online) http://jssidoi.org/jesi/

2020 Volume 7 Number 3 (March)

http://doi.org/10.9770/jesi.2020.7.3(31)

\section{Interpretation and result}

In the article, the analysis of research results consists of two parts, including the research plan presented in Figure 2. Due to the importance of the acquired material in the context of the entire process, the first result presentation path refers to the summary of the qualitative research stage. Its main area of analysis focuses on the recognition and description of the basic conditions conducive to the occurrence of synergy in team work. The results and their interpretation are the starting point for the next part - the preliminary surveys. The intention of the exploratory activities of the second analysis path is the quantitative approach to the issue and presentation of key relations in determining the conditions for the occurrence of synergy. At this stage of the research, an attempt was made to determine the strengthening role of synergy in teams in the context of the relations activity in team work - improving the learning organisation. Thanks to the case study method, in addition to the survey method of data collection, the natural teamwork environment was directly observed, which allowed to understand and justify the obtained results of the study. The effects of the two analysis paths presented in the further part of the article are a reference point for extended studies. The aim of the third stage of research is to compare the conditions of synergy in different teams and organisations and to explain the nature of the synergy mechanism (the results of the third stage of research will be the subject of other articles).

\section{Path of qualitative analysis results}

The grounded theory used in qualitative research has enabled the emergence of concepts, characteristics and indicators important for team work. 7 categories were defined at the sampling stage, and they included (Jasińska, 2019(1)): the quality of relations being shaped, the basis for building teamwork, the effects of team work, team activities, management activities in building teamwork, the course of cooperation and a special type of satisfaction " based on team work. The added value, obtained thanks to the grounded theory strategy, is a proposed definition of synergy, which indicates that: Synergy is the phenomenon of an enhanced outcome (an intensification result of factors interaction) versus the summ of the end-result of individual factors (quality of teamwork). This type of energy generated in the team is an additional contribution to the quality of working together. Synergy is a feature emerging at the level of the excellence of teamwork, the state of greater effects obtained through the growth and use of free and enhanced in the team work activity.

Based on the results of two research stages, it was assumed that the satisfaction(*) of team work is the quantifiable quality measure of synergy. This is the value that the team achieves as a common benefit based on high activity and quality of joint operation. Such satisfaction" can be treated as a "bonus", that improves the result of team work, and happens also thanks to the ability to implement and develop potential in a team, which in the end translates into the desired creative behaviour and innovative action (Jasińska, 2019(2)).

Another effect of qualitative analysis is obtaining empirical evidence, which indicates that the basis for increasing the effectiveness of learning organisation is effective cooperation and proactive behaviour. It was noticed that in the aspect of building the openness and the activity in cooperation, the high quality of relations $\left(\mathrm{r}_{\mathrm{S}}=0,75\right)$, satisfaction $\left(r_{S}=0,73\right)$ and mobilising the effects of team work $\left(r_{S}=0,84\right)$ are significant (Jasińska, 2019(2)). The main assumption, being part of the overall theory (problem and research hypothesis), emerges as the result of qualitative analyses, which consolidates the knowledge gained at this stage of the research, and at the same time opens new possibilities for further research and analytical activities: What conditions of team working are conducive to the emergence of synergy in a team? On the basis of the collected data and observations, it was assumed that: The quality of team work, by means of ensuring appropriate potential, level of relations and stimulating co-operative activity, creates opportunities for synergy. The final step of this path is to construct a set of research tools for the second stage of the study, which prior the third research stage shall be verified. 


\section{ENTREPRENEURSHIP AND SUSTAINABILITY ISSUES}

ISSN 2345-0282 (online) http://jssidoi.org/jesi/

2020 Volume 7 Number 3 (March)

http://doi.org/10.9770/jesi.2020.7.3(31)

\section{Path of quantitative analysis results}

The second stage of analysis is related to the application of quantitative methods used to verify the assumptions. The statistical analysis of the survey results was based on: Pearson's r, confirmatory factor analysis (CFA), basic statistics (arithmetic mean, SD, V), and multiple regression analysis. Cronbach's alpha was used to evaluate the reliability of individual measurements of scale. The first part of the quantitative analysis summarises the indication of the synergy conditions synergy in a team, while the second concerns the interpretation of results, which are an argument for recognising synergy as a strengthening force in improving the learning organisation, especially in conditions of innovative changes.

The conditions for the emergence of synergy in a team, as described in the five main variables, are evaluated in terms of determining the factor loadings (CFA) values (Jasińska, 2019(2)). The results of the confirmatory factor analysis model prove the achievement of high values of loadings for each of the five variables, because they exceed the desired value of 0,7 . Moreover, the high result obtained by verifying the internal consistency of the tool is also the confirmation of the quality of the conducted estimation of these variables. The conditions of synergy are best described by the effects of team work $(0,922 ; \alpha=0,914)$ and cooperation $(0,905 ; \alpha=0,854)$. The second tier, in the assessment of factor loadings, indicates satisfaction ${ }^{*}(0,866 ; \alpha=0,832)$ and the quality of the relations $(0,835 ; \alpha=0,797)$.

Another evidence for the quality of the model's estimation is the high assessment of the dependence between the five variables that explains the conditions for the emergence of synergy in a team. Based on the results of the study, we can indicate the three most characteristic, and yet, the strongest correlations concerning relationship: effects of team work - satisfaction* $(r=0,807)$; cooperation - satisfaction ${ }^{*}(r=0,798)$ and cooperation - effects of team work $(\mathrm{r}=0,796)$. Thus it confirms that in order to create favourable conditions for synergy when building teamwork quality, one should consider, the 3 co-reinforcing factors: cooperation, effects of team work and satisfaction*. Using the basic statistics of the conditions of synergy emerging in the team, assessment of SD parameters and variability coefficient $\mathrm{V}$, it can be assumed that the results of the studied group indicate quite low variability and variation (standard deviation results range from 0,284 to 0,524 and $\mathrm{V}$ from 7,35 to 13,1).

The analysis of the regression model proved that the equation describing the impact of teamwork quality on satisfaction* (in relation to joint action) is statistically significant $(F=142,489$ and $p<0,000)$. On top of that, a good match between 4 independent variables (entrepreneurial potential, quality of relations, cooperation, effects of team work) defining the quality of teamwork, which in $74,5 \%$ validate the qualitative measure of synergy in a team, presented in the form of a dependent variable - satisfaction* $\left(\mathrm{R}^{2}=0,745\right)$, is also visible. Each of the 4 independent variables obtained a high statistic $\mathrm{F}$ and $\mathrm{p}<0.001$ values. The most important for the explanation of the model are cooperation $\left(F=63,97 ; R^{2}=0,676\right)$, effects of team work $\left(F=62,454 ; R^{2}=0,699\right)$ and the quality of the relation $\left(\mathrm{F}=20,263 ; \mathrm{R}^{2}=0,612\right)$ values. Interestingly, the $\mathrm{F}$-value for the entrepreneurial potential $\left(\mathrm{F}=4,896 ; \mathrm{R}^{2}=0,469\right)$ could prove that this variable is co-linear with another one. In this context, the assessment of the relationship indicates the quality of the relation $(r=0,632$ - the highest of all variables) as a variable that can strengthen the significance of this potential. It can be presumed that the quality of the relation is a factor activating and developing the entrepreneurial potential in a team. It is therefore a synergistic factor that intensifies and strengthens the action of others.

Hence a positive influence of 4 variables describing teamwork quality on the satisfaction* value has been demonstrated using the non-standardised regression coefficient $\mathrm{b}$. The cooperation $(b=0,703)$, effects of team work $(b=0,617)$ and the quality of the relation $(b=0,465)$ influence variability of satisfaction* in the greatest extend while the entrepreneurial potential $(b=0,187)$ has the weakest influence of the qualitative measurement of synergy. In the analysed model, the evaluation of the results of the standardised Beta regression coefficient $(\beta)$ 
confirms that also cooperation $(\beta=0,508)$ and the effects of team work $(\beta=0,521)$ are the best predictors validating satisfaction*. Therefore, given the analysed results, it becomes obvious that sense of progress (Amabil T.M., Kramer S.J., 2011) in teamwork, understood as achieving extraordinary effects in working together and achieving the level of excellence of joint action increases the chances of synergy in a team by increasing satisfaction*. In view of the above: The quality of joint action creates opportunities for synergy by providing the appropriate potential, level of relationship and stimulating cooperative activity can be considered a true hypothesis.

The next step in the quantitative analysis of data is the identification of compounds of variables constituting the basis for the description of factors strengthening the learning organisation undergoing a change. In the new approach the significance of the conditions for the occurrence of synergy in a team were taken into account, and the analysis area was expanded by two dimensions. After verification of the scales in the research tool, appropriate data segmentation was carried out, which allowed to identify 5 areas of analysis. As a result of the new data layout, the studied areas were defined with the following indicators:

- Activity in a joint action $\rightarrow$ described by two variables: cooperation - validated by the pursuit of common goals and course of cooperation and the effectiveness of a team.

- Improvement of learning organisation $\rightarrow$ described by two variables: the implementation of changes in an organisation - validated by the direction of changes in an organisation and behaviour towards change and team learning - validated by openness and flexibility in working together, as well as knowledge sharing.

- Social potential $\rightarrow$ validated by two interchangeable variables: entrepreneurial behaviour at work and a network of active relationships.

- Management $\rightarrow$ validated by two variables: managers support of joint-activity and strengthening and rewarding the team's activity.

- Satisfaction ${ }^{*} \rightarrow$ measured directly by 10 features describing mainly the sense of joint action meaningfulness, opportunities for potential development and awareness and value of progress in a team.

The carried out correlation analyses revealed the existence of statistically significant interdependencies. They occur between the 5 main conditions for the development of a learning organisation, described by: active participation, improvement of learning organisation, satisfaction", social potential, management. The presentation of the results is presented in Figure 4.

\begin{tabular}{|c|c|c|c|c|c|}
\hline Activity in team working & - & & & & \\
\hline $\begin{array}{l}\text { Improvement of learning } \\
\text { organisation }\end{array}$ & 0,586 & - & & & \\
\hline Satisfaction* & 0,611 & 0,753 & - & & \\
\hline Social potential & 0,441 & 0,447 & 0,44 & - & \\
\hline Managemet & 0,249 & 0,475 & 0,415 & 0,504 & - \\
\hline $\mathrm{N}=200 ; \mathrm{p}<0,001$ & $\begin{array}{l}\text { Activity in team } \\
\text { working }\end{array}$ & $\begin{array}{l}\text { Improvement of } \\
\text { learning } \\
\text { organisation }\end{array}$ & Satisfaction* & Social potential & Managemet \\
\hline
\end{tabular}

Fig. 4. Pearson's correlation results of the learning organisation development

Source: own study. 


\section{ENTREPRENEURSHIP AND SUSTAINABILITY ISSUES}

ISSN 2345-0282 (online) http://jssidoi.org/jesi/

2020 Volume 7 Number 3 (March)

http://doi.org/10.9770/jesi.2020.7.3(31)

The highest values of correlation coefficients were recorded in the case of satisfaction*, improvement of learning organisation and activity in team working. A qualitative measure of synergy in a team (satisfaction*) is the strongest relationship with improvement of a learning organisation $(r=0,753)$ and activity in a joint action $(\mathrm{r}=0,611)$. The improvement of the organisation, in addition to satisfaction* is highly related with the activity in the joint action $(r=0,586)$. Thus we say about the mutual interdependence of three factors that are important for the development of any organisation. There was also a relatively high dependence between social potential and management $(\mathrm{r}=0,503)$. This result indicates that a proactive management, providing an adequate support of entrepreneurial activities, building good relationships between people and strengthening and rewarding the team's activity, creates good development foundations of social potential. The quality of potential, used in building activity in a joint action, that is appropriately strengthened increases the possibilities of improving the learning organisation. This is especially important in conditions of innovative changes. The other investigated correlations are also statistically significant. The least significant dependence was demonstrated between activity in team working and management $(r=0,249)$. This proves that the way of management is not such an important variable that determines the quality of joint action. Probably there may be an intermediary variable in this relationship that will strengthen this relationship. It can be assumed, based on the results of the analysis, that the mediating variable in this system is the social potential, which shows quite significant relation with management $(r=0,503)$ and activity in a team working $(r=0,441)$. The distinction of the most important relations of factors validating the conditions for the development of an organisation is the basis of the next step in the quantitative analysis. Further activities are related to determining the value of factor loadings based on confirmatory factor analysis (CFA). The obtained results are presented in Figure 5.

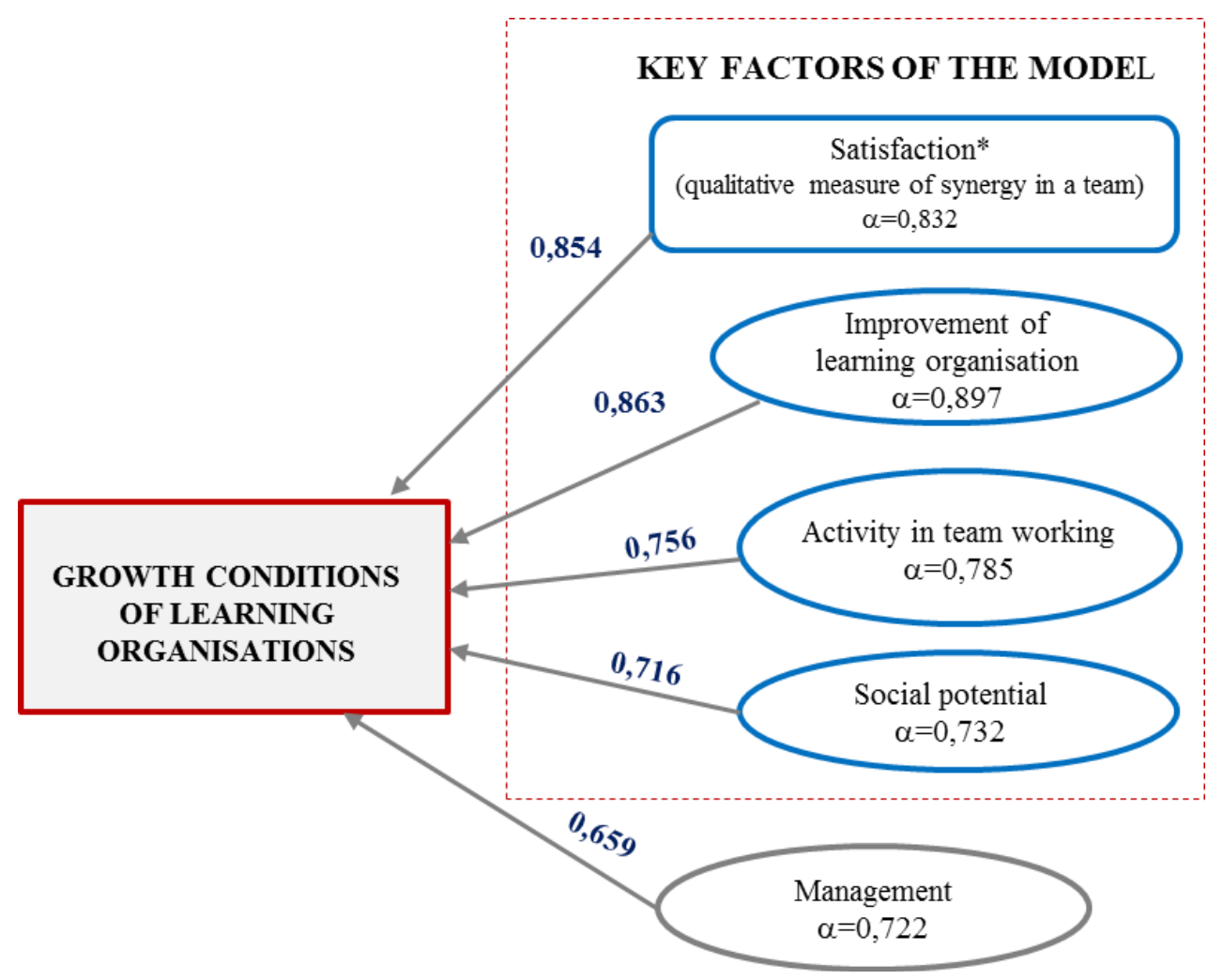

Fig. 5. Results of factor analysis (CFA) and assessment of Cronbach's alpha reliability factors validating development conditions of learning organisations

Source: own study. 
The estimation of CFA model indicates a high value of factor loadings describing the development conditions of learning organisation. Four out of the five loadings obtained the desired 0,7 value, and the fifth had a similar one, thus individual variables typical for development conditions seem to make a good match.

Two variables: improvement of learning organisation $(0,863)$ and satisfaction* $(0,854)$ got the highest factor loading. At the same time, the quality of the analysis is clearly substantiated by high results of level of measurement's reliability, which was determined against the most significant values of loadings: improvement of learning organization $\alpha=0,897$ and satisfaction ${ }^{*} \alpha=0,832$. The second tier in the estimation of loadings was demonstrated for activity in a joint action $(0,756 ; \alpha=0,785)$ and social potential $(0,716 ; \alpha=0,732)$. The result, which represents the lowest value of all loadings, was also acceptable since it did not deviated greatly from the desired 0,7 value. This observation refers to the factor loading - management $(0,659)$, whose internal coherence of the level of measurement is quite high $\alpha=0,722$. CFA analysis generally points to a good fit of factor loadings, where the variables best validating the development conditions of a learning organisation are organisational improvement and satisfaction*. The results of the analysis are consistent with the analysis of the correlation coefficient and constitute a continuation point for data interpretation in the next area of the analysis.

The next stage of the quantitative approach when assessing the conditions of growth of a learning organisation is to present the values of the basic statistics, based on the data presented in Table 2.

Table 2. Characteristics of teams in individual and focus group interviews

\begin{tabular}{|c|c|c|c|}
\hline Variables in the model & $\begin{array}{c}\text { Average rating } \\
\text { Arithmetical } \\
\text { Average }\end{array}$ & $\begin{array}{c}\text { Standard } \\
\text { Deviation } \\
\text { SD }\end{array}$ & $\begin{array}{c}\text { Coefficient of variation } \\
\text { V (\%) }\end{array}$ \\
\hline Satisfaction* & 3,975 & 0,578 & 14,5 \\
\hline The activity in the joint action & 3,861 & 0,379 & 9,82 \\
\hline $\begin{array}{c}\text { Improvement of learning } \\
\text { organisation }\end{array}$ & 3,707 & 0,569 & 15,35 \\
\hline $\begin{array}{c}\text { Potential social movements } \\
\text { Managing method }\end{array}$ & 3,681 & 0,431 & 19,79 \\
\hline $\mathrm{N}=200$. & 3,137 & 0,621 & \\
\hline
\end{tabular}

Source: own study.

On average, the obtained parameters of individual variables indicate that their level can be assessed from quite low - management $(3,14)$, to medium - social potential $(3,68)$ and organisational improvement $(3,71)$, and to rather high - activity in team working $(3,86)$ and satisfaction* $(3,97)$. With regard to the teams under examination, this result indicates a clear need to improve teamwork management, the managers therefore, are required to promote more the entrepreneurial activities and create more favourable climate for the development of social capital in teams, they are also to apply an appropriate rewarding system, which directly impacts the proactive behaviour, openness to change and knowledge sharing. 


\section{ENTREPRENEURSHIP AND SUSTAINABILITY ISSUES}

ISSN 2345-0282 (online) http://jssidoi.org/jesi/

2020 Volume 7 Number 3 (March)

http://doi.org/10.9770/jesi.2020.7.3(31)

This direction of thinking and acting is the basis for team learning and increasing commitment in implementing innovative changes. The previous analyses have already showed that if the mechanism of enhancing the quality of teamwork, through a proactive management and properly developed and utilised social potential, works, the activity of joint action will increase. This effect, in turn, will translate into the openness and direction of organisation's improvement, and it will increase the level of satisfaction of joint action.

The analysis of data presented in table 2 takes into account the classical measurement of dispersion variance in form of standard deviation, as well as the assessment of the variation coefficient V. Based on this information, it is possible to indicate a small variability and diversity in relation to the answers provided. This is confirmed by the SD parameters in the context of the five variables studied, which range from 0,379 to 0,621 . This result determines a fairly small standard deviation, i.e. indicates a small variation. In turn, the variation coefficient V defines the range of values from 9,82 to 19,7 and is the empirical evidence that the studied group is not very different in terms of the way of assessing the examined features. The analysis determines that the activity in team working shows the smallest variability and differentiation among all assessed features, and the way of management demonstrates the greatest. In the context of joint activity, there is a similar way of assessing factors that are important for ensuring the quality of teamwork. It was agreed that the most important is the course and organisation of cooperation and the effectiveness of team activities. Bearing in mind results of management, one should point out to a different way of interpreting the mechanism of influencing by the management team / team leaders. There may also be various expectations as to the method of support and rewards. The main observation is that the role of managers is to build an atmosphere of proactivity in order to stimulate the development of entrepreneurial potential and ensure the proper quality of the relationship.

Taking into account the results of the analyses presented in the article, the following information was obtained:

1. Pearson's $r$ analysis of dependencies $\rightarrow$ satisfaction*, improvement of the learning organisation and activity in team working demonstrated the highest values of correlation coefficients. These variables show a strong codependence: satisfaction ${ }^{*}$ - improvement of organisation $(r=0,753)$; satisfaction ${ }^{*}$ - activity in team working $(\mathrm{r}=0,611)$; improvement of organisation - activity in a joint action $(\mathrm{r}=0,586)$.

2. Confirmatory factor analysis (CFA) $\rightarrow$ highest values of factor loadings were achieved by improvement of learning organisation $(0,863)$, satisfaction ${ }^{*}(0,854)$ and activity in team working $(0,756)$.

3. Analysis of the basic statistics (mean, SD and V-coefficient) $\rightarrow$ satisfaction* $(3,97)$, activity in team working $(3,86)$ and improvement of organisation $(3,71)$ obtained the highest mean ratings. Activity in team working $(\mathrm{SD}=0,379 ; \mathrm{V}=9,82)$, satisfaction* $(\mathrm{SD}=0,578 ; \mathrm{V}=14,5)$, as well as improvement of the learning organisation $(\mathrm{SD}=0,569 ; \mathrm{V}=15,35)$ shows one of the smaller values describing variability and differentiation.

The summary of the analysis determines the reasons for selecting the relevant variables, which are included in the next stage of the statistical data elaboration. The obtained empirical evidence is therefore a justification for the development of a mediation model based on multiple regression. The aim of the analysis of this model is to verify the assumption on the mediating role of the qualitative measure of synergy (satisfaction ${ }^{*}$ ) in the relations between the activity in the joint action and the direction of improvement in learning organisation. Therefore, a dependent variable - improvement of organisation, an independent variable - activity in a joint action and mediator satisfaction* (a qualitative measure of synergy in a team) have been distinguished in the mediation model. Figure 6 shows the structure of the mediation triangle and obtained results. 


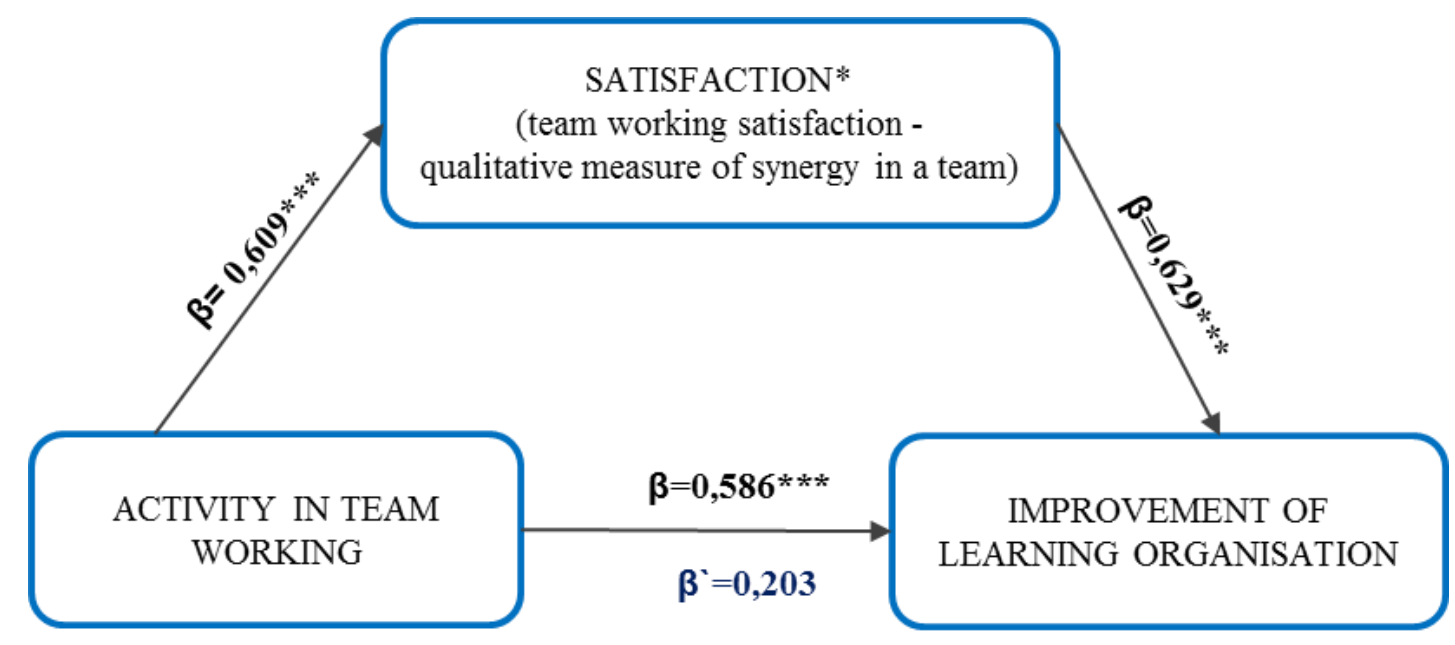

\section{Significance level $* * * p<0,001$}

Fig. 6. Mediating model showing impact of activity in team working on improvement of an organisation, in which the qualitative manifestation of synergy in a team is the satisfaction* mediator

Source: own study.

The regression analysis in three subsequent steps (Baron R.M., Kenny D.A., 1986) explain whether the synergy, emerging in teamwork, strengthens the improvement of learning organisation:

1. Inspect if the relationship between the independent variable - activity in the joint action and the dependent variable - improvement of organisation is statistically significant (path C, figure 3 ).

2. Establish if the relationship between the independent variable - activity in a joint activity and mediator satisfaction* (path A, figure 3) and the mediator and dependent variable - improvement of organisation (path B, figure 3 ) is statistically significant.

3. Analyse if after introducing the satisfaction* mediator into the model, the relationship between the independent variable - activity in a joint action and the dependent variable - improvement of organisation weakens (path $\mathrm{C}^{\prime}$, Fig. 3).

The results of $\beta$ coefficients obtained in the regression analysis resulting from the structure of mediation relationships are presented in Table 3. 
Table 3. Regression coefficients of relations resulting from the structure of mediation dependencies - the independent variable (activity in a joint operation) - dependent variable (improvement of organisation)

\begin{tabular}{|c|c|c|c|c|c|}
\hline \multicolumn{6}{|c|}{ Dependent variable - Improvement of learning organisation } \\
\hline \multirow[b]{2}{*}{ Model } & \multicolumn{2}{|c|}{ Non-standardised coefficients } & Standardised & \multirow{2}{*}{$\mathrm{t}$} & \multirow{2}{*}{$\begin{array}{c}\text { Significance } \\
p\end{array}$} \\
\hline & $b$ & Standard error & Beta $(ß)$ & & \\
\hline Absolute term & 0,3177 & 0,3682 & & 0,8628 & 0,3895 \\
\hline Activity in team working & 0,8779 & 0,0950 & 0,5865 & 9,2461 & 0,000 \\
\hline \multicolumn{6}{|c|}{ Dependent variable - Satisfaction* (qualitative measure of synergy in a team) } \\
\hline \multirow{2}{*}{ Model } & \multicolumn{2}{|c|}{ Non-standardised coefficients } & $\begin{array}{c}\text { Standardised } \\
\text { coefficients }\end{array}$ & \multirow[t]{2}{*}{$\mathrm{t}$} & \multirow{2}{*}{$\begin{array}{c}\text { Significance } \\
p\end{array}$} \\
\hline & $b$ & Standard error & Beta $(ß)$ & & \\
\hline Absolute term & 0,3983 & 0,3664 & & 1,0870 & 0,2786 \\
\hline Activity in team working & 0,9271 & 0,0945 & 0,6093 & 9,8107 & 0,0000 \\
\hline \multicolumn{6}{|c|}{ Dependent variable - Improvement of learning organization } \\
\hline \multirow{2}{*}{ Model } & \multicolumn{2}{|c|}{ Non-standardised coefficients } & $\begin{array}{l}\text { Standardised } \\
\text { coefficients }\end{array}$ & \multirow[t]{2}{*}{$\mathrm{t}$} & \multirow{2}{*}{$\begin{array}{c}\text { Significance } \\
p\end{array}$} \\
\hline & $b$ & Standard error & Beta $(ß)$ & & \\
\hline Absolute term & 0,0713 & 0,2921 & & 0,2440 & 0,8076 \\
\hline Activity in the joint action & 0,3044 & 0,0947 & 0,2034 & 3,2159 & 0,0016 \\
\hline $\begin{array}{l}\text { Satisfaction * } \\
\text { (qualitative measure of synergy in the team) }\end{array}$ & 0,6187 & 0,0622 & 0,6289 & 9,9450 & 0,0000 \\
\hline
\end{tabular}

Source: own study.

Results of testing the mediation dependence (tab. 3) in the model (Figure 6) showed the following conclusions:

1. In the first regression equation, the direct dependence - activity in the joint operation and improvement of organisation was confirmed. The regression model proved to be well suited to the data and indicated that the higher the level of activity in the joint action, the better the organisation progresses towards innovative changes $(\beta=0,586, \mathrm{p}<0,001)$ (path $\mathrm{C}$, figure 3 ).

2. The second step of the analysis, tested the relationship between the independent variable - activity in a joint action and the mediator - satisfaction* (path A, figure 3) and the mediator and dependent variable - the improvement of organisation (path $\mathrm{B}$, fig. 3). These relationships proved to be statistically significant $(\beta=0,609 ; p<0,001 ; \beta=0,629 ; p<0,001)$, and the models to be well-fitted to the data. This means that the second condition for the existence of mediation has been met. 


\section{ENTREPRENEURSHIP AND SUSTAINABILITY ISSUES}

ISSN 2345-0282 (online) http://jssidoi.org/jesi/

2020 Volume 7 Number 3 (March)

http://doi.org/10.9770/jesi.2020.7.3(31)

3. In the mediating model that includes both the independent variable and the mediator (path $\mathrm{C}^{\prime}$, Fig. 3 ), the role of activity in the joint operation decreased $(\beta=0,203 ; p<0,001)$ but it maintained the level of statistical significance. The satisfaction" mediator was strongly associated with the improvement of organisation - the dependent variable $(\beta=0,629 ; \mathrm{p}<0,001)$. Therefore, it can be concluded that the introduction of synergy as a mediator changed the prediction of activity in a team work ftowards improvement of organisation. The analysis also indicates that satisfaction* - a qualitative measure of synergy is a predictor of improvement of the learning organisation under the conditions of change. Synergy strengthens team's learning, knowledge sharing, creativity, openness, flexibility towards change, and commitment to creating change. This favours the innovative development of teams and learning organisations.

The value of the Sobel test, for the $\mathrm{b}$ values and standard error introduced in the presented regression analyses (Table 3), turned out to be statistically significant $(Z=5,435 ; p<0,001)$. This confirmed the mediating role of synergy (in terms of its qualitative measure - satisfaction*) in the impact of activity in team work on the improvement of organisation. Given the positive outcome of the analyses, the the hypothesis can be positively considered: Synergy (measured by a qualitative measure - satisfaction ${ }^{*}$ as an increased effect emerging on the basis of high activity in a joint action strengthens the improvement of learning organisations in the area of innovative changes

\section{Conclusion}

The application of the grounded theory and the qualitative analysis of data allow to diagnose conditions conducive to the occurrence of synergy in a team. The research showed that well-arranged cooperation, measurable effects of joint action, high quality of relationships and a special type of satisfaction* (satisfaction of joint action) are stimulating synergy in team work. As the outcome of the study a synergy definition has been suggested. The definition describes the synergy as a phenomenon of an enhanced effect versus the result of individual factors. This is the kind of energy created in a team, which boosts the quality of working together. Synergy is the feature, it is the level of team-working excellence achieved by increasing activity stimulated by creative work of a team.

The research confirmed that activity in team working, the direction of improvement of organisation, and satisfaction* are the key factors stimulating development of learning organisations in conditions of a change. Moreover, it was also indicated that the management method and social potential are not the team's internal forces that could directly and independently create conditions for the emergence of synergy. Their role is to mutually strengthen actions when setting up an environment for team learning, sharing knowledge and demonstrating a proactive behaviour. In addition, during the analysis, an observation emerged that the quality of relationships in a team can be considered as a synergistic factor that stimulates other factors, e.g. the entrepreneurial potential, and generates an additional effect. Referring to the developed mediation model, it was indicated that the synergy expressed by the qualitative measure - satisfaction ${ }^{*}$ has the status of a mediator in $h$ the relation of activity of joint action with the improvement of the learning organisation, therefore it is the development strength of learning organisations. The enhancing impact of synergy translates into creativity and the implementation of innovative changes. With all that in mind, one can assume that the concept of creating apt team working conditions that foster synergy boosts organisation's chances and a real-time opportunity to experience an innovative growth. The available papers on the aspect confirm the results of the developed analyses. Moreover, concepts that can be used for a fuller explanation, understanding and wider application in the modern organisation management are the theory of learning organisations (Sange P., 2014), knowledge (Earl M., 2001; Easterby-Smith M., Lyles M., 2003) and innovation (Ries E., 2011) management, and creative organisation (Florida R., 2014; Bilton C., Cummings S., 2010) or teams X (Ancona D., Bresman H., 2007). 


\section{ENTREPRENEURSHIP AND SUSTAINABILITY ISSUES}

ISSN 2345-0282 (online) http://jssidoi.org/jesi/

2020 Volume 7 Number 3 (March)

http://doi.org/10.9770/jesi.2020.7.3(31)

\section{References}

Albrecht, K. 2003. The power of minds at work. Organizational intelligence in action, American Management Association, New York.

Amabile, T.M., Kramer, S.J. 2011. The power of small wins. Harvard Business Review, 89(5), 70-80. https://hbr.org/2011/05/the-powerof-small-wins

Ancona, D., Bresman, H. 2007. X-teams: How to Build Teams That Lead, Innovate and Succeed, Harvard Business Review Press.

Baron, R.M., Kenny, D.A. 1986. The moderator-mediator variable distinction in social psychological research: Conceptual, strategic and statistical considerations. Journal of Personality and Social Psychology, 51, 1173-1182.

Benešová, D., Kubičková, V., Michálková, A., Krošláková, M. 2018. Innovation activities of gazelles in business services as a factor of sustainable growth in the Slovak Republic. Entrepreneurship and Sustainability Issues, 5(3), 452-466. $\underline{\text { https://doi.org/10.9770/jesi.2018.5.3(3) }}$

Bilton, C., Cummings, S. 2010. Creative strategy. Reconnecting business and innovation, Chichester Wiley.

Bratianu, C. 2015. Organizational Knowledge Dynamics: Managing Knowledge Creation, Acquisition, Sharing, and Transformation, Hershey: IGI Global.

https://www.researchgate.net/publication/281032869 Organizational Knowledge Dynamics Managing Knowledge Creation Acquisitio n_Sharing_and_Transformation

Černevičiūtè, J., Strazdas, R. 2018. Teamwork management in Creative industries: factors influencing productivity, Entrepreneurship and Sustainability Issues 6(2): 503-516. https://doi.org/10.9770/jesi.2018.6.2(3)

Charmaz, K. 2014. Grounded Theory in Global Perspective: Reviews by International Researchers. http://citeseerx.ist.psu.edu/viewdoc/download?doi=10.1.1.858.8343\&rep=rep1\&type=pdf

Corning, P. 2018. Synergistic Selection: How Cooperation Has Shaped Evolution and the Rise of Humankind, World Scientific Publishing Co Pte Ltd.

Corning, P.A. 1996. The co-operative gene: On the role of synergy in evolution. Evolutionary Theory 11, $183-207$. http://complexsystems.org/publications/the-co-operative-gene-on-the-role-of-synergy-in-evolution/

Earl, M. 2001. Knowledge management strategies. Journal of Management Information Systems, 18(1), 215-223.

Easterby-Smith, M., Lyles, M. 2003. The Blackwell handbook of organizational learning and knowledge management, Oxford, Blackwell.

Florida, R. 2014. The Rise of the Creative Class: And How It's Transforming Work Leisure Community and Everyday Life, Brilliance Audio.

Garvin, D.A. 1993. Building a Learning Organization, Harvard Business Review, No. July-August. https://hbr.org/1993/07/building-alearning-organization

Huber, G.P. 1999. Organizational learning: the contributing processes and the literatures. Organization Science, 2(1), 88-115.

Jasińska, M. 2015. Synergy, the result of intelligent cooperation. http://www.irdo.si/skupni-cd/cdji/cd-irdo-2015/referati/15-monikajasinska-paper.pdf

Jasińska, M. 2019. Synergy in a team - quality analysis of conditions, Zeszyty Naukowe Uniwersytetu Przyrodniczo-Humanistycznego w Siedlcach $\quad \mathrm{Nr} \quad$ 120, Seria: Administracja $\quad$ i $\quad$ Zarządzanie $\quad$ (47), https://repozytorium.uph.edu.pl/bitstream/handle/11331/2378/M.Jasinska_Synergy_in_a_team_quality_analysis_of_conditions.pdf?sequen $\underline{\mathrm{ce}=5}$

Jasińska, M. 2019. Recognition and description of synergy conditions in team work in view of the grounded theory. Entrepreneurship and Sustainability Issues, 7(1), 375-397. http://doi.org/10.9770/jesi.2019.7.1(27) 


\section{ENTREPRENEURSHIP AND SUSTAINABILITY ISSUES}

ISSN 2345-0282 (online) http://jssidoi.org/jesi/

2020 Volume 7 Number 3 (March)

http://doi.org/10.9770/jesi.2020.7.3(31)

Jelenic, D. 2011. The Importance of Knowledge Management in Organization- with Emphasis on the Balanced Scorecard Learning and Growth perspective, Management Knowledge \& Learning, International Conference.

Kaur, S. 2015. Knowledge Management, International Journal of Management and Commerce Innovations, Vol. 3, No. 2, $1085-1089$.

King, W.R. 2009. Knowledge Management and Organizational Learning. http://www.uky.edu/ gmswan3/575/KM_and_OL.pdf

King, W.R. (ed.) 2009. Knowledge Management and Organizational Learning, Annals of Information Systems 4, Vol. 3, Springer-Verlag New York Inc.

King, W.R., Chung, R.T., Haney, M.H. 2008. Knowledge Management and Organizational Learning. The International Journal of management Science, Omega, 36, 167-172.

Konecki, K.T. 2011. Visual Grounded Theory: A Methodological Outline and Examples from Empirical Work, 131-160. https://www.researchgate.net/publication/233991214_Visual_Grounded_Theory_A_Methodological_Outline_and_Examples_from_Empiri cal_Work

Konecki, K.T. 2009. Teaching Visual Grounded Theory. Qalitative Sociology Review. https://www.researchgate.net/publication/233991153 Teaching Visual Grounded Theory. https://hrcak.srce.hr/file/106256

Loermans, J. 2002. Synergizing the Learning Organisation and Knowledge Management. Journal of Knowledge Management, 6 (3).

Maull, R., Brown, P., Cliffe, R. 2001. Organisational culture and quality improvement. International Journal of Operations \& Production Management, 21(3), 302-326.

Nonaka, I. 1991. The Knowledge-Creating Company, Harvard Business Review, No. November-December.

Park, S.H., Zhang, Y., Keister, L.A. 2019. Governance innovations in emerging markets, Academy of Management Perspectives, In-Press. https://journals.aom.org/doi/10.5465/amp.2017.0177

Ries, E. 2011. The Lean Startup, Crown Business, New York.

Rusly, F.H., Corner, J.L., Sun, P. 2012. Positioning change readiness in knowledge management research. Journal of Knowledge Management, 16 (2).

Senge, P., Kleiner, A., Roberts, Ch., Ross, R., Roth, G., Smith, B., Guman, E.C. 2007. The dance of change: The challenges to sustaining momentum in learning organizations. https://doi.org/10.1002/pfi.4140380511

Senge, P.M. 2014. The fifth discipline fieldbook: Strategies and tools for building a learning organization, Crown Business, New York.

Tidd, J. 2012. From Knowledge Management to Strategic Competence, Imperial College Press, London.

Tidd, J., Bessant, J.R., Pavitt, K. 2015. Managing Innovation: Integrating Technological, Market and Organization Change, John Wiley \& Sons Ltd. Chichester.

Tidd, J., Bessant, J.R. 2018. Managing Innovation: Integrating Technological, Market and Organizational Change, John Wiley \& Sons Ltd. Chichester. 
ENTREPRENEURSHIP AND SUSTAINABILITY ISSUES

ISSN 2345-0282 (online) http://jssidoi.org/jesi/

2020 Volume 7 Number 3 (March)

http://doi.org/10.9770/jesi.2020.7.3(31)

\section{Acknowledgements}

The paper has been prepared on the basis of a fundamental research project - Synergy and Social Capital of Modern Organisations. The project was financed by the National Science Centre with funds allocated on the basis of decision-DCE 2011/01 / BHS4 / 04810.

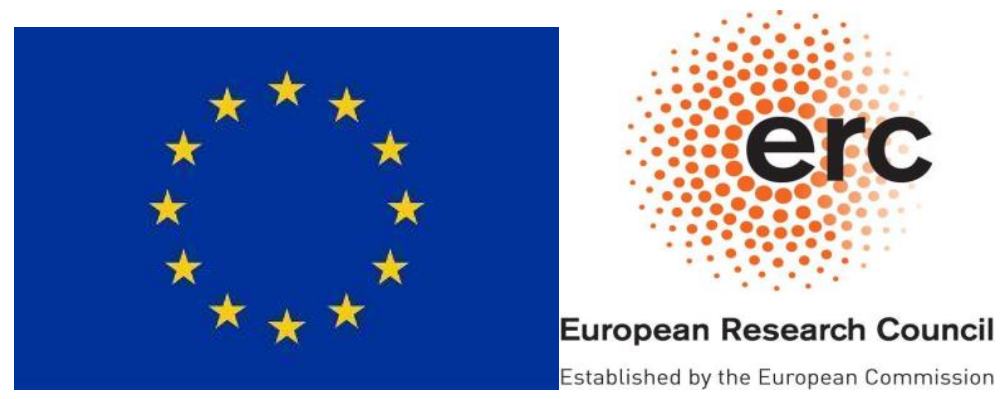

Monika JASIŃSKA $\mathrm{PhD}$ in politics, specialist in management and public administration. Currently, she works in the Department of Organisation and Management of the Faculty of Economics and Legal Sciences of Siedlce University of Natural Sciences and Humanities. She is a member of the Advisory Council of the Polish Agency for Enterprise Development Research Centre. She is focuses on developing synergy in teams, researching learning organisations, growing social and human capital in organisations. She studies the development of entrepreneurship and innovation and building active conduct in organisations. At present her work deals with synergy in modern organisations. Her researches include innovation aspects, effective team working and knowledge management. She manages research projects, which are often conducted in cooperation with the industry to get the ultimate result i.e. improvement of organisation management.

ORCID ID: orcid.org/0000-0001-9231-4469

Copyright (C) 2020 by author(s) and VsI Entrepreneurship and Sustainability Center This work is licensed under the Creative Commons Attribution International License (CC BY). http://creativecommons.org/licenses/by/4.0/ 